\title{
Analysis of Factors Hypertension in Online-Based Transportation Driver in Kediri City
}

\author{
Arif Mustofa, Nurwijayanti, \\ Rahmania Ambarika ${ }^{3}$ \\ Institute of Health Science Strada \\ Indonesia, Kediri \\ Email: \\ mustofaarif495@gmail.com
}

Received : October 10, 2020

Accepted : November 23, 2020

Published : November 30, 2020

\begin{abstract}
One of the actions that can be taken to prevent hypertension is to develop knowledge about the level of vulnerability on several factors that influence it. It is expected that with enough knowledge to feel the level of vulnerability can increase awareness of hypertension. The purpose of this study was to determine the effect of the level of vulnerability on factors of sleep quality, stress, and eating patterns on hypertension in online-based transportation drivers in Kediri City. The research design used is quantitative research using the "cross sectional" approach. The sampling technique used was simple random sampling with a sample of 164 respondents. The data analysis technique uses a logistic regression multivariate test. The results showed that the sleep quality variable a significance value of $0,000<(\alpha=0.05)$, meaning that $\mathrm{H} 0$ is rejected and $\mathrm{H} 1$ is accepted which means that there is an influence between sleep quality on the incidence of hypertension. In the stress variable it is known a significance value of $0.004<(\alpha=$ $0.05)$, meaning that $\mathrm{H} 0$ is rejected and $\mathrm{H} 1$ is accepted, which means that there is an influence between stress levels on the incidence of hypertension. In the variable eating patterns it is known a significance value of $0,000<(\alpha=0.05)$, meaning that $\mathrm{H} 0$ is rejected and $\mathrm{H} 1$ is accepted which means that there is an influence between eating patterns on the incidence of hypertension. Knowledge of the level of vulnerability to the causes of hypertension can increase one's awareness of the dangers of the disease so that they can take early precautions and protect themselves from the threat of the disease.
\end{abstract}

Keywords: Hypertension, Sleep quality, Stress, Eating patterns

Copyright @ 2020 IIK STRADA Indonesia All right reserved.

This is an open-acces article distributed under the terms of the Creative Commons Attribution-ShareAlike 4.0 International License.

\section{BACKGROUND}

Hypertension is a condition of increasing a person's systolic blood pressure to be more or equal to $140 \mathrm{mmHg}$ and a distolic blood pressure of more or equal to $90 \mathrm{mmHg}$. According to Smeltzer and Bare (2002), hypertension can be defined as a persistent blood pressure where the systolic blood pressure is above $140 \mathrm{mmHg}$ and the diastolic blood pressure is above $90 \mathrm{mmHg}$. Hypertension often does not cause serious symptoms, but if the blood pressure is kept elevated for a long time it can cause complications. Therefore, regular and periodic blood pressure checks are highly recommended to prevent these complications. 
In its development, hypertension has become a factor in the occurrence of several diseases related to cardiovascular disease and stroke. According to the World Health Organization (2010) hypertension is a major health problem in the world because of its high prevalence rate and is directly related to an increased risk of cardiovascular disease. In 2030, it is estimated that cardiovascular disease will be the main cause of death in humans of productive age in their development, which is predicted to reach $41 \%$ (Topp and Frost, 2006). Developments in the fields of industrialization, urbanization, economic development, and population growth in the current era of globalization are also contributing factors in increasing this risk.

According to the Ministry of Health's report (2013) states that hypertension is one of the causes of death for the population, where the proportion reaches $6.7 \%$ of the population of deaths at all ages in Indonesia. Based on the 2013 Riskesdas results, the prevalence of hypertension sufferers reaches $25.8 \%$ and it is estimated that hypertension sufferers in Indonesia reach 15 million people. Meanwhile, the results of Riskesdas 2018, the number of hypertension sufferers in Indonesia has increased with a prevalence of $34.1 \%$. This is because many hypertension sufferers are not aware of themselves as hypertension sufferers, so that many people tend to suffer from heavier hypertension.

Based on the results of Riskedas of East Java Province in 2018, it shows that the prevalence of hypertension sufferers is at $36.2 \%$. This number increased from the number of Riskesdas reports for the previous period in 2013 which reached 26.2\%. Meanwhile, Kediri City itself has also experienced a significant increase in the number of hypertension sufferers. Based on the results of Riskesdas 2018, it shows that the prevalence of hypertension sufferers in Kediri City reaches 36\%. In the previous period, namely, the 2013 Riskesdas report, the prevalence of hypertension sufferers in Kediri was only $26 \%$.

The cause of the higher incidence of hypertension is thought to be due to the changing lifestyle of the people along with the times as it is today. Lifestyle is an important factor affecting people's lives. An unhealthy lifestyle can be the main cause of hypertension, for example physical activity and stress (Puspitorini in Sount et al, 2014).

In addition to an unhealthy lifestyle that can lead to hypertension, other factors that can trigger the disease are sleep quality and poor diet. The quality of sleep is one of the most important factors in maintaining one's health. Efficiency of tired sleep is known to be one of the risk factors for hypertension and the use of optimal sleep hours can help prevent hypertension in a person. According to Asmarita (2014), the cumulative effect of prolonged sleep deprivation or sleep disturbances is also associated with increased mortality and increased risk for various chronic diseases including depression, hypertension, stroke, type 2 diabetes, heart disease, and obesity.

The wrong diet can also be one of the triggers for hypertension in a person. According to AS (2010), consumption of modern foods can be one of the main factors in the occurrence of hypertension. An unhealthy diet in today's practical era has an impact on irregular consumption patterns. Excess intake of fat results in increased levels of fat in the body, especially cholesterol which causes weight gain so that blood volume experiences a greater increase in pressure (Ramayulis, 2010). In addition, consumption of foods with excess salt levels can also increase extracellular blood volume which results in the onset of hypertension (Sutanto, 2010).

Apart from changes in lifestyle, current technological developments have also triggered the emergence of various kinds of new professions. One of the professions that has undergone a change is the provision of transportation services that were previously conventional based, which has now developed into online-based. In the modern era, people have various activities and to fulfill these activities, people need transportation as a supporting tool in their activities. In Indonesia today, it is often found that motorbikes have been used by the community as a means of public transportation, such as for transporting people and goods and then charging fees for these services as agreed. This type of transportation is commonly known as a motorcycle taxi.

Changes in work patterns made by online-based motorcycle taxi drivers are often considered too draining to drivers. The increasing number of users of this mode of transportation makes application providers also increase the number of drivers every day. Competition between drivers, both from drivers with the same applicator and from other application providers to get orders from customers, adds to the driver's workload to be heavier. The close point system imposed by application providers to get bonuses according to the points earned every day also forces drivers to work longer and harder than usual. This has the potential to trigger a pattern of behavior change at work to become 
unhealthy so that it can become a factor in the occurrence of hypertension in online-based motorcycle taxi drivers.

High stress levels can lead to hypertension in a person. Stress can stimulate the child's kidney glands to release adrenaline and stimulate the heart to beat faster and stronger, so that blood pressure will increase (Depkes RI, 2006). The initial study conducted in this study through an interview with 30 online transportation drivers showed that 18 drivers had complaints of hypertension and symptoms of hypertension. The results of the interview also revealed that 13 drivers had hypertension after they joined online transportation drivers. This indicates that the changing pattern of work behavior before and after becoming an online transportation driver greatly affects the incidence of hypertension among these online transportation drivers. This problem is thought to occur when the driver feels uncomfortable with the rules applied by the application provider. The close point system implemented by the application provider forces drivers to work longer than before, which can trigger fatigue that is often complained of by drivers. In addition, the number of drivers who are considered too many in Kediri City creates competition in getting orders so that many drivers choose to do work by going around. Unfavorable weather and pollution factors often make drivers feel uncomfortable and lead to more serious health problems. Based on the background described above, the researcher was interested in conducting a research entitled "Analysis of Factors for the Occurrence of Hypertension in Online-Based Transportation Drivers in Kediri City".

\section{OBJECTIVE}

This study aims to determine the factors that influence the occurrence of hypertension in online transportation drivers. Irreversible factors such as high stress levels, risky eating patterns, and poor sleep quality are all too common among today's online transportation drivers. This is a direct result of the irregular job pattern of an online transportation driver.

\section{MATERIALS AND METHODS}

The research design used was quantitative research with a cross sectional approach. The number of samples used in this study were 164 respondents who were online transportation drivers in Kediri and had been randomly selected. The research was conducted by taking the necessary data using an observation sheet and questionnaire that had been prepared previously. The data collection process is carried out at one time for all variables. The dependent variable in this study is the incidence of hypertension in online transportation drivers. While the independent variables are sleep quality, stress levels, and diet for online transportation drivers. The data that has been collected will be tested using the logistic linear regression statistical test to determine the effect of the independent variable on the dependent variable. This research has also been done through the Strada Indonesia Health Sciences Institute Kediri research ethics commission with Number : 1653/KEPK/XI/2019

\section{RESULTS}

Table 1 Distribution Frequency Characteristics of Respondents of Online-Based Transportation Drivers in Kediri City, 2020.

\begin{tabular}{clcc}
\hline No & Respondent Age & (f) & $(\%)$ \\
\hline 1 & $\leq 30$ years & 46 & 28 \\
2 & $31-40$ years & 53 & 32,3 \\
3 & $41-50$ years & 43 & 26,2 \\
4 & $>50$ years & 22 & 13,4 \\
& Total & 164 & 100.0 \\
\hline No & Length of Work of Respondents & $(\mathrm{f})$ & $(\%)$ \\
\hline 1 & $\leq 12$ month & 30 & 18,3 \\
2 & $13-24$ month & 79 & 48,2
\end{tabular}




\begin{tabular}{clcc}
3 & $>24$ month & 55 & 33,5 \\
& Total & 164 & 100.0 \\
\hline No & Respondent's Height & $(\mathrm{f})$ & $(\%)$ \\
\hline 1 & $\leq 160 \mathrm{~cm}$ & 43 & 26,2 \\
2 & $161-170 \mathrm{~cm}$ & 90 & 54,9 \\
3 & $>170 \mathrm{~cm}$ & 31 & 18,9 \\
& Total & 164 & 100.0 \\
\hline No & Respondent's Weight & $(\mathrm{f})$ & $(\%)$ \\
\hline 1 & $\leq 50 \mathrm{~kg}$ & 21 & 12,8 \\
2 & $51-60 \mathrm{~kg}$ & 42 & 25,6 \\
3 & $61-70 \mathrm{~kg}$ & 42 & 25,6 \\
4 & $71-80 \mathrm{~kg}$ & 50 & 30,5 \\
5 & $>80 \mathrm{~kg}$ & 9 & 5,5 \\
& Total & 164 & 100.0 \\
\hline No & Respondents' Body Mass Index (BMI) & $(\mathrm{f})$ & $(\%)$ \\
\hline 1 & Less weight & 11 & 6,7 \\
2 & Ideal weight & 76 & 46,3 \\
3 & Excess weight & 77 & 47 \\
& Total & 164 & 100.0 \\
\hline
\end{tabular}

Source: Primary Data (2020)

Based on the research data in table 1, it is known that out of 164 respondents, the characteristics of respondents, seen from the age of the driver, were mostly respondents with the age of 31-40 years with a number of 53 people $(32.3 \%)$. (48.2\%), the highest body height of respondents was $161-170 \mathrm{~cm}$ as many as 90 people (54.9\%), the most body weight was $71-80 \mathrm{~kg}$ as many as 50 people (30.5\%), and index the most body mass was excess body weight as many as 77 people (47\%).

Table 2. Distribution Frequency Characteristics Variables of Respondents of Online-Based Transportation Drivers in Kediri City, 2020.

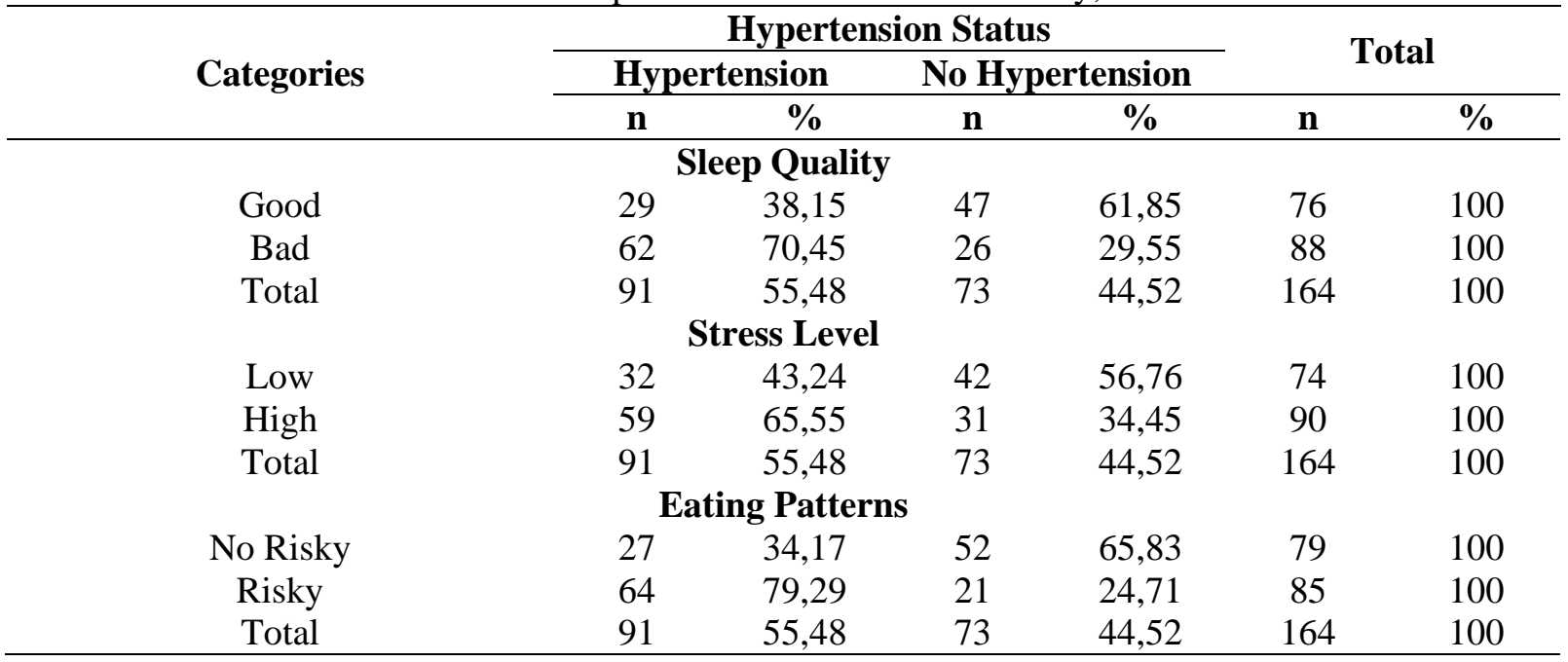

Source : Primary Data (2020)

Based on the data in table 2 above, it is known that most respondents have poor sleep quality and experience hypertension, as many as 62 people (37.8\%). In the stress level variable, it is known that most respondents have high stress levels and experience hypertension, as many as 59 people (35.97\%). Meanwhile, in the dietary variable, it is known that most respondents have a risky diet and experience hypertension, as many as 64 people (39\%). 
Table 3 Results of the Statistical Analysis of Model Summary Test

\begin{tabular}{cccc}
\hline Step & -2 Log likelihood & Cox \& Snell R Square & Nagelkerke R Square \\
\hline 1 & $174.108 \mathrm{a}$ &, 268 &, 599 \\
\hline
\end{tabular}

a. Estimation terminated at iteration number 5 because parameter estimates changed by less than , 001

Source: Primary Data (2020)

Based on the results of the model summary test, table 4.17. above, it can be seen that the model incorporating two independent variables has actually influenced changes in the parameter estimation (-2 Log likelihood) of 174.108. Meanwhile, based on data from the Cox \& Snell R Square value, which is 0.268 , it can be statistically concluded that the incidence of hypertension in onlinebased transportation drivers in Kediri is influenced by the quality of sleep, stress, and diet of the driver, which is $26.8 \%$. while the remaining $72.2 \%$ is influenced by other factors.

Table 4 Results of Multivariate Logistic Linear Regression Test

\begin{tabular}{lccccc}
\hline \multirow{2}{*}{ Independent Variable's } & \multirow{2}{*}{ Exp (B) } & \multirow{2}{*}{ R Square } & \multicolumn{2}{c}{ CI (95 \%) } & \multirow{2}{*}{ P Value } \\
\cline { 4 - 5 } & & & Lower & Upper & \\
Sleep Quality & 4,314 & 0,101 & 2,048 & 9,088 & 0,000 \\
Stress Level & 2,804 & 0,049 & 1,338 & 5,879 & 0,006 \\
Eating Pattern's & 5,843 & 0,161 & 2,793 & 12,220 & 0,000 \\
\hline \multicolumn{1}{c}{ N Observasi } & 164 & & & & \\
\hline
\end{tabular}

Source: Primary Data (2020)

Referring to the results of the logistic regression multivariate statistical test in Table 4.18. above, it can be seen that all independent variables have a significant effect on the dependent variable. In addition, it is also known that the most dominant variable in influencing the incidence of hypertension is the dietary variable, which is $16.1 \%$ ( $\mathrm{R}$ Square $=0.161$ ).

In the variable sleep quality, it is known that the value of $p=0.000$, which means that the variable sleep quality has a statistically significant effect on the incidence of hypertension in onlinebased transportation drivers in Kediri. Statistically, sleep quality has an effect of $10.1 \%$ on the incidence of hypertension experienced by the driver $(\mathrm{R}$ Square $=0.101)$. The value of Exp $(B)$ shows the number 4,314, which means that the worse the quality of sleep in an online transportation driver in Kediri, the risk is 4 times higher for hypertension than those who have good sleep quality.

The stress variable shows that the value of $p=0.006$, which means that the stress variable has a statistically significant effect on the incidence of hypertension in online-based transportation drivers in Kediri City. Statistically, the stress level has an effect of $4.9 \%$ on the incidence of hypertension experienced by the driver $(\mathrm{R}$ Square $=0.049$ ). The $\operatorname{Exp}(\mathrm{B})$ value of 2.804 shows that statistically online-based transportation drivers in Kediri City who have a high stress level are 3 times more likely to develop hypertension when compared to other drivers who have a low stress level.

The $\mathrm{p}$ value of the dietary variable shows $\mathrm{p}=0.000$, it can be concluded that the dietary variable has a statistically significant effect on the incidence of hypertension in online-based transportation drivers in Kediri. Statistically, diet has an effect of $16.1 \%$ on the incidence of hypertension experienced by the driver $(\mathrm{R}$ Square $=0.161)$. The value of $\operatorname{Exp}(\mathrm{B})$ is known to be 5,834 , which means that statistically drivers who have a diet are 6 times more likely to develop hypertension than drivers who have a diet that are not at risk of hypertension.

\section{DISCUSSION}

\section{The Effect of Sleep Quality on the Incidence of Hypertension in Online-Based Transportation Drivers}

The results showed that the characteristics of respondents based on sleep quality were dominated by respondents who had poor sleep quality, as many as 88 people (53.7\%). While some 
others have good sleep quality, as many as 76 people (46.3\%). Through research data, it can be seen that as many as 62 people (36.6\%) or nearly half of the total number of respondents have poor sleep quality and experience hypertension. A small proportion of respondents, as many as 26 people (15.9\%), had poor sleep quality but did not experience hypertension.

In theory, sleep is a time of repair and preparation for the next waking period. As long as the body is in a state of sleep, biological functions will decrease. The normal heart rate in healthy adults throughout the day averages 70 to 80 beats per minute or lower if the individual is in perfect physical condition. However, during sleep the rate drops to 60 beats per minute or lower. This means that the heart rate is 10 to 20 times less per minute of sleep or 60 to 120 times less per hour. Clearly, deep sleep is beneficial in maintaining heart function (Potter \& Perry, 2005).

The results showed that the average online transportation driver had a sleep duration of 5.7 hours per day. Short sleep duration is associated with hypertension, especially in middle age. Insomnia with short sleep duration is also associated with an increased risk of hypertension. This is because sleep activity can change the function of the autonomic nervous system and other physiological events that affect blood pressure. In addition, sleep disturbances alter the blood pressure response and increase the risk of hypertension.

During normal sleep there is a decrease in relative blood pressure during wakefulness. This decrease is due to decreased sympathetic nerves. A drop from $10 \%$ to $20 \%$ in blood pressure compared to mean blood pressure during the day is considered normal. Conversely, any normal decrease that should occur and not be experienced by someone, there is a $20 \%$ chance that there will be an increase in blood pressure. Activation of the hypothalmic-pituitary-adrenal axis and the sympathetic nervous system as seen in insomnia can lead to susceptibility to the development of hypertension (Calhoun \& Harding, 2010).

Blood pressure will increase when we are active, which is when the heart has to pump harder. For example, when doing sports. However, when we rest the blood pressure will decrease. This situation is caused by a decrease in the burden on the heart. Food, alcohol, pain, stress, and overwhelming emotions can also raise blood pressure. Even when dreaming, blood pressure can increase. However, this situation is normal.

A person's blood pressure usually changes over time. Within 24 hours, the blood pressure in the arteries naturally fluctuates for 24 hours. The highest blood pressure usually occurs in the morning after waking up and doing activities. After that, blood pressure stabilizes throughout the day and at night the blood pressure begins to drop. Blood pressure will reach its lowest point when we are fast asleep (Yulianti \& Sitanggang, 2006).

From the research results it is known that the worse the sleep efficiency of the driver, the greater the risk of developing hypertension. This is in line with research conducted by Javaheri (2008), that lack of sleep is a risk factor for hypertension in adults. Although the cause is unclear, experimental studies show that the resulting shorter sleep can lead to metabolic and endocrine disorders that can contribute to cardiovascular disorders. In addition, it was also reported that although low sleep duration can cause hypertension, low sleep efficiency is reported to have more meaning to cause hypertension than low sleep duration (Javaheri et al., 2008).

Overall, this study has shown that the quality of sleep of an online transportation driver greatly affects the occurrence of hypertension, where drivers with poor sleep quality have the potential to develop hypertension 4 times greater than drivers who have good sleep quality. These results are in line with research conducted by Bansil et al., (2011) which suggests that in people with both sleep disorders and short sleep, we found that hypertension was more likely to occur twice in people without these problems. This association is likely the result of a biological mechanism, suggesting that sleep deprivation can alter the stress hormone cortisol and sympathetic nerves, resulting in an increase in blood pressure.

\section{The Effect of Stress Level on the Incidence of Hypertension in Online-Based Transportation Drivers}

The results showed that the characteristics of respondents based on stress levels were dominated by respondents with high stress levels, namely 91 people (54.9\%). Meanwhile, some others have a low level of vulnerability to the quality of sleep for 74 people $(45.1 \%)$. Through research data, 
it can be seen that as many as 59 people (36\%) or almost half of the total respondents have a high level of stress on stress and experience hypertension. A small proportion of respondents, as many as 31 people (18.9\%) had a high level of stress on stress but did not experience hypertension.

Stress is an activity of sympathetic nerves, this increase affects the gradual increase in blood pressure. If the stress becomes prolonged, it can result in blood pressure being fixed or getting higher. Hypertension occurs due to the interaction of various factors. Stress is the fear and anxiety of our feelings and bodies about changes in the environment. Physiologically, if something threatens the pituitary gland, the brain will send signals and hormones to the endocrine glands which then circulate the adrenal hormone from hydrocortisone to the blood. As a result, the body becomes ready to adapt to changes that arise. Naturally what we feel is a racing heartbeat and cold sweat that usually flows down the nape of the neck.

The results showed that most of the drivers experienced high anxiety and anxiety. Some drivers stated that this was triggered by a sense of injustice in the work division system which was considered very burdensome for drivers. In addition, the commission distribution system and incentives that they felt were not in favor of them greatly influenced their psychological conditions when working in the field.

A person's psychological condition affects blood pressure, for example the psychological condition of a person who experiences stress or pressure. The body's response to stress is called an alarm, which is a defense reaction or resistance response. This condition is characterized by an increase in blood pressure, heart rate, respiratory rate, and muscle tension. In addition, stress also results in an increase in blood flow to the brain. In addition, stress also results in increased blood flow to the skeletal muscles and decreased blood flow to the kidneys, skin and digestive tract. Stress will make the body produce more adrenaline, this makes the heart work stronger and faster (Lawson.R, 2007).

Indeed, in stressful conditions the body immediately adjusts to the pressure that comes. This is why it is often said that stress exceeds the body's usual endurance or ability. However, these bodily adjustments can cause physical and psychological disorders. The presence of adrenaline and hydrocortisone hormones which are produced as the body's reaction to stress when it is excessive and lasts for a long time can cause a series of reactions from other organs of the body.

From the research results, it can also be seen that stress levels affect the occurrence of hypertension in online transportation drivers. Drivers with high stress levels are three times more likely to develop hypertension than drivers with low or no stress levels. The functional changes in blood pressure at several sites can be caused by acute stress, if repeated intermittently several times can cause a structural adaptation of cardiovascular hypertrophy.

Stress is an activity of sympathetic nerves, this increase affects the gradual increase in blood pressure. If the stress becomes prolonged, it can result in blood pressure being fixed or getting higher. Likewise, the stress experienced by people with hypertension will affect the increase in their blood pressure which tends to remain even higher or become severe. When this occurs at the vascular level there will be an increase in resistance, which is due to an increase in the ratio of the vessel wall to its leumen.

\section{The Effect of Eating Pattern's on the Incidence of Hypertension in Online-Based Transportation Drivers}

The results showed that the characteristics of respondents based on diet were dominated by respondents with a diet that was at risk of hypertension, namely as many as 85 people $(51.8 \%)$. Meanwhile, some others have a eating pattern's that is not at risk for 79 people (48.2\%). Through research data, it can be seen that as many as 64 people (39\%) or nearly half of the total number of respondents have a risky diet and experience hypertension. A small proportion of respondents, as many as 21 people (12.8\%), had a risky diet but did not experience hypertension.

Eating pattern's is a way of how we regulate a balanced nutritional intake that is needed by the body. Adjusting the diet or diet is one way to deal with hypertension without serious side effects because the control method is more natural when compared with blood pressure-lowering drugs that can make patients become dependent on these drugs permanently (Sustrani, 2006). 
The results showed that a diet high in fat and sodium has a significant effect on the incidence of hypertension among online transportation drivers in Kediri. This is in line with research conducted by Nancy et al. (2012) which states that there is a significant relationship between a high-fat diet and the occurrence of hypertension. Consumption of foods that are high in fat can cause atherosclerosis or narrowing of the blood vessels, which can cause blood vessels to become stiff and reduce elasticity. This condition will increase resistance to blood flow in the blood vessels. The increase in systolic and diastolic pressure is caused by narrowing of the blood vessels which will eventually lead to hypertension or what is commonly referred to as high blood pressure (Saraswati, 2009).

In addition to consuming foods high in fat, foods that contain excess sodium are said to be one of the triggers for high blood pressure. The effect of sodium intake on the onset of hypertension occurs through an increase in plasma volume, cardiac output, and blood pressure (Susalit et al. 2001). Excess sodium consumption causes the concentration of sodium in extracellular fluid, to dilute the intracellular fluid is drawn out so that the extracellular fluid increases. The increase in the volume of extracellular fluid causes an increase in blood volume, resulting in high blood pressure.

Apart from resulting in constriction of blood vessels, excessive food consumption can also lead to obesity or excess weight in a person. The results showed that $47 \%$ of online transportation drivers were overweight which tended to lead to obesity. When you gain weight you get mostly fatty tissue, this tissue relies on oxygen and nutrients in the blood to survive. The more blood that passes through the artery, the more pressure is received by the artery wall. Nearly everyone who is $20 \%$ overweight will eventually develop high blood pressure.

Epidemiological investigations have proven that obesity is a characteristic feature of the hypertensive patient population (Tjokronegoro, 2001; Vasilios K., 2010; Theodore). In the condition of obesity, there is an increase in the amount of free fatty acids which will narrow the blood vessels so that it increases. Heart pump power and circulating blood volume of obese patients with hypertension are higher than those of normal body weight (Susalit et al. 2001).

The results showed that diet is the most dominant factor in influencing an increase in blood pressure in online transportation drivers in Kediri. Drivers with a high-risk diet have a 6 times greater chance of developing hypertension when compared to drivers who have a non-risk diet. This is in line with the research conducted by Nancy (2012) which states that the factor of fat intake is the factor that has the greatest influence on the occurrence of hypertension, where the elderly with fat consumption of more than $25 \%$ of total calories per day have a risk 3.3 times greater for suffering from hypertension.

The job as an online transportation driver which requires someone to work all day long on the streets makes most drivers ignore their diet by consuming fast food. The uncontrolled consumption menu causes most drivers to care less about the ingredients and nutritional content contained in these foods. A healthy diet can be defined as a way or an effort to do healthy eating. Diet also determines health for the body. The wrong diet is one of the risk factors that increase hypertension.

Modern food factors are a major contributor to hypertension (US, 2010). A healthy lifestyle and a healthy diet are the right choices to keep yourself free from hypertension. Everything is done continuously, it must not be temporary. Once carelessly guarding yourself by not following a healthy lifestyle, you will certainly be susceptible to hypertension. Types of foods that cause hypertension are ready-to-eat foods that contain preservatives, too high salt levels in food, excess consumption of fat (Susilo, 2011).

Therefore, limiting food consumption that can cause hypertension should be started early before hypertension appears, especially in people who have a hereditary history of hypertension and in people who are approaching old age. The main principle in carrying out a healthy diet Hypertension by reducing salt intake, weight loss in obese people, increasing potassium intake from vegetables and fruit and intake of whole grains such as the DASH Diet has been proven to be an effective strategy to control blood pressure (Heller, 2016).

\section{CONCLUSION}


There is a significant influence between sleep quality on the incidence of hypertension in online-based transportation drivers in Kediri, where drivers with poor sleep quality have a 4.3 times greater risk of developing hypertension when compared to drivers who have good sleep quality.

There is a significant influence between the level of stress on the incidence of hypertension in online-based transportation drivers in Kediri, where drivers with high stress levels have a 2.8 times greater risk of developing hypertension when compared to drivers with low stress levels.

There is a significant influence between eating patterns on the incidence of hypertension in online-based transportation drivers in Kediri, where drivers with a risky of eating patterns are 5.8 times more likely to develop hypertension when compared to drivers who have a non-risk of eating patterns.

The most dominant factor in influencing the occurrence of hypertension in online-based transportation drivers in Kediri is eating patterns, where this factor has an effect of $16.1 \%$ on the incidence of hypertension in drivers.

\section{ACKNOWLEDGMENT}

We give the best gratitude to all taxi drivers in Hayam Wuruk (HW) Kediri, Gaspool Kediri, and Solidaritas Grab Kediri comunities for support. We also give the gratitude to all respondents who have been willing and participated on this study.

\section{CONFLICT OF INTEREST}

This study did not have any conflict of interest.

\section{REFERENCES}

AS, M. (2010). Hidup Bersama Hipertensi. Yogyakarta: In Book

Asmarita, I. (2014). Hubungan Antara Kualitas Tidur Dengan Tekanan Darah Pada Pasien Hipertensi

Di Rumah Sakit Umum Daerah Karanganyar. Naskah Publikasi. Universitas Muhammadiyah Surakarta.

Ministry of Health RI. (2013). Riset Kesehatan Dasar. Jakarta: Badan Penelitian dan Pengembangan Kesehatan.

Riskesdas. (2018). Riset Kesehatan Dasar. Jakarta: Badan Penelitian dan Pengembangan Kesehatan

Nancy SHM., Lucia KD., Pangastuti, Retno. (2012). Pola Makan dan Konsumsi Alkohol Sebagai

Faktor Risiko Hipertensi pada Lansia. Jurnal Gizi Klinik Indonesia: 8(4): 202-212.

Ramayulis, R. (2010). Menu dan Resep Untuk Penderita Hipertensi. Jakarta: Penebar Plus

Smeltzer \& Bare. (2002). Buku Ajar Keperawatan Medical Bedah Brunner-Suddarth. Jakarta: EGC

Sount, M, Bidjuni, H, Malara, RT. (2014). Hubungan Gaya Hidup Dengan Kejadian Hipertensi Di

Puskesmas Kolongan Kecamatan Kaawat Kabupaten Minahasa Utara 2014. Jurnal Keperawatan (e-Kp), 2(1): 1-10

Susalit, E., Kapojos, EJ., Lubis, HR. (2001). Hipertensi Primer. Dalam: Suyono, SH. Buku Ajar Ilmu Penyakit Dalam Edisi 3. Jakarta: Balai Penerbit FK UI.

Sutanto. (2010). Cekal (Cegah \& Tangkal) Penyakit Modern. Yogyakarta: ANDI

Topp, R \& Frost, K.L. (2006). Exercise for The Inactife Hypertensive Patient. School of Nursing University of Louisville. Ethnicity and Disease, 16, 27-34. 